\title{
Literacy environment of pupils in urban primary schools
}

\author{
M.P. Machet* \& S.I.I. Olën \\ Department of Information Science, University of South Africa, P.O. Box 392, Pretoria, 0001 Republic of South Africa \\ machemp@alpha.unisa.ac.za \& olensii@alpha.unisa.ac.za
}

Received December 1996; accepted March 1997

\begin{abstract}
In this article the literacy environment of urban primary school pupils is investigated. A literature survey has been carried out on various aspects of the literacy environment including preliteracy, emergent literacy, contracts and metacontracts of literacy, the role of the school library and the culture of reading. This is followed by a discussion of in-depth interviews that were carried out with 25 primary school children in standards 3 and 4 to establish their literacy environment. Finally, various recommendations are made as to the role of the school library to improve the literacy environment and address problem areas as well as suggested activities for teachers and teacher librarians. This research formed part of a larger research project on the effect of free voluntary reading by primary school pupils on their English second language.
\end{abstract}

Die geletterdheidsomgewing van stedelike laerskoolleerlinge word in hierdie artikel ondersoek. 'n Literêre ondersoek is gedoen oor verskeie aspekte van die geletterdheidsomgewing insluitende pre-geletterdheid, ontwikkelende geletterdheid, kontrakte en metakontrakte van geletterdheid, die rol van die skoolbiblioteek en die leeskultuur. Dit is opgevolg deur 'n bespreking van indiepte-onderhoude wat gehou is met 25 laerskoolkinders in Standerd 3 en 4 om hulle geletterdheidsomgewing te bepaal. Laastens word verskeie aanbevelings gemaak ten opsigte van die rol van die skoolbiblioteek ten einde die geletterdheidsomgewing te verbeter, probleemareas word aangespreek en aktiwiteite vir onderwysers en onderwyserbibliotekarisse word voorgestel. Hierdie navorsing is deel van 'n groter navorsingsprojek oor die effek van 'n vrywillige leesprogram op Engels as tweede taal deur laerskoolleerlinge.

*Author to whom correspondence should be addressed.

Education authorities in the new South African government want to improve the quality of education by inter alia improving literacy levels, encouraging critical thinking and producing lifelong learners. However, they do not necessarily see that the establishment and maintenance of school libraries with a variety of relevant resources could play a major role in achieving these goals. Also at present all the provincial education departments are struggling to meet their commitments because of the lack of funds and as a result of the backlogs in schools in terms of facilities, equipment, textbooks and teacher training. Even where good school libraries/ media centres exist there are insufficient funds to maintain good collections and many full-time and part-time teacherlibrarians have been re-allocated to subject teaching.

A further problem is that previous to 1992 the school population tended to be drawn from a homogenous language and socio-economic group. Today this is no longer the case and schools are having to cater for a heterogenous group of pupils.

In this article a number of pupils from standards 3 and 4 were interviewed to establish their literacy environment. The interviews formed part of a larger research project on the effects of free voluntary reading on English second-language pupils (Olën, Machet \& Kloppers, 1996). Aspects which were investigated were the literacy environment at home, preliteracy, emergent literacy, the culture of reading and the role that school libraries can play.

\section{Literacy environment}

\section{Literacy environment at home}

In South Africa many parents are illiterate and do not have the discretionary income to enable them to afford to buy books for their children. They opt out of the child's education not because of disinterest but because they feel that they have nothing to give the child that will be of value. Many children are no longer experiencing the rich oral culture of storytelling - an important preliteracy experience. Parents are too busy and too tired in the evenings to spend time telling young children stories. Also, many parents feel that their oral culture of storytelling does not have a value in today's high-tech world. Thus children are deprived of any form of storytelling.

According to 1991 figures, $34.5 \%$ of all blacks have not been to school while $45.2 \%$ completed primary school only (Spangenberg as quoted by Tötemeyer 1994:412). Chakava (as quoted by Tötemeyer 1994:413) is of the opinion that once formal education has ended, most Africans do not continue reading for pleasure, mainly because more pleasure is derived from oral and aural interaction than from the private and individual activity of reading a book. Amadi (also cited by Tötemeyer 1994:413), believes that literacy by itself does not culminate in a print mentality. White (1985:115) mentions ignorance, stress and lack of assistance as further obstacles to the attainment of literacy.

Certain factors in the home environment have been identified as playing a role in literacy. Three out-of-school factors affecting achievement in reading and mathematics were identified by Alspaugh (1991:53): 
- eligibility for free lunch (indicates the financial support available to students);

- a two-parent home (an indicator of the homelife of the pupils); and

- student mobility, that is the number of pupils entering and leaving school during the school year (an indicator of the stability of the student's environment).

He found that over $50 \%$ of the variance in second-grade reading and over $40 \%$ of the variance in mathematics achievement could be attributed to these three factors. These factors may be found in many South African homes. Thembela (1982:15) has identified the following as the social consequence of more than forty year's apartheid:

- overcrowded and inadequate housing;

- family disorganization;

- a high rate of illegitimacy; and

- malnutrition and child neglect.

These factors all have a negative affect on the literacy environment of the child.

\section{Preliteracy}

An essential element of a child's literacy environment is the extent of their preliteracy experience. Literacy entails more than just decoding skills - it is a complex, constantly developing process that involves a wide range of skills, experience and understanding. In order to become literate a child must acquire skills that are only remotely related to print as well as those that are directly related. Research shows that many of the skills which are used in reading are learnt before the child goes to school (Heath 1983). These preliteracy skills are not taught at school because until recently they were not even identified and their importance was not recognized (Dickenson et al. 1992, Miles 1995, Weinberger 1996).

Many of the skills needed for successfully learning to read are taught through the process of a parent or caregiver reading aloud to a child. Research indicates that reading aloud to children is the single best predictor of later reading success (Miles 1995:34). In spite of this, research in America shows that only half the infants and toddlers are read to by their parents (Trelease 1995:48). Statistics for South Africa are not available but with high rates of illiteracy, poverty and oneparent.families there is likely to be an even smaller percentage of parents reading to preschool children.

Children who have been read to at home learn to read earlier, better and with more ease at school. This is because the desire to read has been created, the attention span has improved and a better developed vocabulary has emerged, including a better idea of sequencing (Trelease as quoted in Olën 1990:383). Elley (1989:177) found in his research of primary school pupils in the South Pacific Islands that reading stories aloud is an important source of incidental English second-language learning.

Rereading books is also very important as it allows children to internalize many features such as story structure and vocabulary. Children need to hear stories more than once as each time they hear the story they pick up more detail and focus on different aspects. Research shows that an important indicator of whether or not a child has had the necessary preliterate experience is if the child can identify and name a favourite book (Weinberger 1996:23).

A child growing up in a literate family environment (where reading, writing and the sharing of stories occur as part of the normal daily routine) is at a distinct advantage when s/he starts school, as compared to those pupils without reading preparation at home. The latter lack preliteracy skills and therefore find it more difficult to grasp their lessons at school and become less able to keep up with the academic curriculum (Wells 1986:193). It is thus imperative that parents be aware of the importance of language experiences like reading aloud, rhymes and storytelling. Schooling is based on the assumption that children possess these skills.

Many South African children will, however, enter primary school lacking preliteracy skills because they come from disadvantaged homes with no reading tradition. In addition, the first two conditions for encouraging a child to read are often missing in these homes, that is access to books and comfort and quiet (Krashen 1993:37). Children therefore need to acquire the preliteracy skills as soon as possible after entering primary school. Simmons (1994:18) advocates prereading strategies to encourage reading and to create an awareness of the relevance of books in one's life. She discusses strategies like Sort and Predict, Key Visuals, Anticipation Guide and Building from Clues. She believes that they could demonstrate to pupils that reading is more than just a means to an end.

In the United States it was found that poor, minority and immigrant children are not performing well at school. Research showed that the parents of these children want to equip them with linguistic, social and cultural skills, but often are unaware of how to do so (Edward 1995:563). However, parents appreciate being told of the importance of sharing and reading books with their young children. The same author cautions that family literacy programmes must be careful not to create the impression that they are blaming the pupil nor imply that the homes of these families are lacking in literacy. The attitude of 'we know and you don't know' should also not filter through. Come and Fredericks (1995:567) also believe that parents are a major ingredient in literacy development. If parents are convinced the school has their needs and those of their children at heart, they will be more likely to support literacy programmes.

Therefore parents, no matter what their social or economic status, can make an educational difference in their children's lives if allowed to become part of the education team. Radebe (1995:167) mentions the case of working-class parents in Australia who, to escape the hardship of their lives, use books and libraries for escapism as well as a means of advancement. It appears as if a growing number of Africans in this country are sending their children to public libraries to support their reading development (Pranag cited in Radebe 1995:167). Children with limited literacy preschool experience have less 
understanding about the purposes of literacy or how to derive meaning from print than their peers (Weinberger 1996:16).

\section{Emergent literacy}

Children who have been read to have the following patterns of emerging literacy:

- They pay attention to books and information derived from books.

- They acknowledge questions about books.

- They respond to conversational references to the content of books.

- They behave as question-answerers who have knowledge of books.

- They accept book and book-related activities as recreation (Heath 1982:52-3).

- They develop reflective modes of thought associated with literacy (Olson \& Astington 1990).

- They begin to reflect on units of language such as words and syntax.

- They become familiar with the type of language found in books.

- They learn how books convey meaning.

- They develop a more extended and varied vocabulary.

- They internalize schema or frameworks related to text.

- They learn ways of talking about books that they will encounter when they enter school.

- They become familiar with print (Dickenson et al., 1992: 324).

- They acquire the oral language skills associated with literacy.

After completion of a 15-year longitudinal study of Bristol preschool children, Wells (1986:193) explained just how crucial these emergent literacy skills are and how early the differences between children are established. When the children in their study entered school their rank order was already fairly firmly established. Of course school made a difference and the children all made progress, but where schools provide a similar learning environment 'individual children did not change their relative position in the rank order very much'.

Schools build on the child's literate experiences brought from home. Children whose experiences with and expectations of text are replicated and built on in the school environment, will be successful students.

\section{Contracts and metacontracts of literacy}

Very few of the rules of literacy are explicit or can be taught explicitly. Reading and comprehending texts depend on many tacit or implied ways of handling, interacting with and interpreting books which are accepted by literate people. These concern the use of books and the meaning of texts - and have very little to do with the ability to decipher a written word (Snow \& Ninio 1986:121). Snow and Ninio (1986:121) term these the contracts and metacontracts of literacy. Some of these are:
- Books are for reading not manipulating unlike other objects.

- In book reading the book is in control: the reader is led and the book is dominant.

- The book controls what the reader is to think about while reading.

- Pictures are not things but representatives of things. The nature of book input is symbolic.

- Pictures are for naming and the appropriate behaviour is that pictures and words are to be read.

- Pictures though static can represent events. Children are taught to relate several pictorial components to each other to see the emergent whole. This teaches the child narrative structure and sequencing.

- Books constitute an autonomous fictional world and book time is separate and takes place outside real time (Snow \& Ninio 1986:121-136).

\section{Role of the school library}

In countries which do not have many bookshops or where these are not easily accessible, school libraries are a particularly important source of reading matter. Whereas developed countries such as New Zealand have one book shop for every 7500 inhabitants, South Africa has only one book shop for every 100000 inhabitants (Kantey 1990:xv). In this country books are expensive and income is usually spent on the basic necessities and not on 'luxury' items like books. Krashen (1989:454) points out that if reading is such an effective activity there is a need for better stocked libraries.

According to Kinnell (1995:21) findings on children's reading and access to books that were reported in both the Bullock and Whitehead reports showed that school libraries and school library support services are essential for the success of the new modes of teaching and learning. The size of the school library is also directly linked to reading ability, thus it is a prerequisite that a large collection of books is available in order for the reading programme to be effective (Elley \& Mangubhai 1983:66). A study by Lance, Welborn and Hamilton-Pennell (1993:92) demonstrated that the school library impacts positively on academic achievement. The researchers found that the size of both the school library staff and collection is second only to the absence of risk conditions (e.g., poverty, low adult education attainment) when it comes to predictors of academic achievement.

In an analysis of schools that have been successful in promoting independent reading it was discovered that one of the reasons for the success is ready access to books (Anderson, Wilson \& Fielding 1985:78). Nine evaluative studies of a 'book flood' approach, which entails exposing pupils to large quantities of high-interest story books, provided evidence of rapid improvements in reading and listening comprehension. In addition, these improvements appear in all aspects of the pupil's target language (Elley 1991:408).

An investigation by Morrow and Weinstein (1986:34) among second-grade pupils found that literature use increased substantially when teachers employed enjoyable literary 
activities during the regular reading programme and when library centres were created in the classrooms. The significance of this study lies in the discovery that it is not only those pupils who read well who become voluntary readers but that poor readers will be encouraged by a supportive literary environment. Anderson, Wilson and Fielding (1985:51) note 'there is no substitute for a teacher who reads children good stories. It whets the appetite of children for reading ... a practice that should continue throughout the grades'. It has also been suggested that the teacher-librarian be invited into the classrooms to read to the children as meeting him/her on an informal, non-authoritarian basis could reveal the pleasures and benefits of reading (Filson 1992:402). Harris and Baskin (1989:31) state that librarians have always advocated content above skills. Their attitude is encapsulated in the statement: 'Those who don't read are little better off than those who can't'.

In Ross and Postlethwaite's (1994:147) research into factors that affect reading achievement in 32 countries, one of the factors that consistently correlated with reading achievement was that of books in a school. This was found to be especially important for younger children. Books 'are essential no matter how rich or poor a nation is'.

\section{In-depth interviews}

In-depth interviews were conducted as part of a larger research project to establish the effect of free voluntary reading on English second-language acquisition and comprehension of primary school pupils (Olën \& Machet 1997). The analysis of the research results did not indicate a correlation between the amount the children read voluntarily for a readathon and their reading comprehension or second-language acquisition. The researchers therefore thought it possible that factors in the literacy environment could have affected reading comprehension. They also wanted to see if there was a connection between reading motivation and literacy environment as there was no link between the amount read for the readathon and reading ability. They also asked children about their likes and dislikes to see whether the class collection which had been specially chosen for ESL pupils had helped to motivate reading.

It was decided that in-depth interviews would be the best way to determine the literacy environment as the children all spoke English as a second language. The interviewer could explain questions not understood by the children. Also the children might not be able to express themselves in written form as clearly as in spoken form. Young children's command of written language is usually far below that of spoken language.

Based on the literature survey, questions were worked out to examine important factors in the literacy environment. The interviewer had a list of questions that she asked each child. The interviewer was familiar to the children as she had participated in testing the children's comprehension and read stories to the children. This is important as an unfamiliar interviewer can have an inhibiting effect on children. The interviews were recorded and later analyzed.

Altogether 25 children were interviewed in depth, six children from standard 3 and seven children from standard 4 at the experimental school and six from standards 3 and 4 at the control school. The pupils in the experimental school were selected on the basis of the two who had improved the most in the comprehension tests (three in standard 4), the two who had improved the least in the comprehension tests and the two who had read the most. In the control school they were selected on the basis of the two who had improved the most in the comprehension tests, two whose improvement was average, and the two who had improved the least.

\section{Discussion of the data}

The data was interpreted and will be discussed on the basis of aspects that affect the literacy environment as identified in the literature survey.

The children were generally found to come from homes with relatively favourable conditions for literacy. All the homes except one had electricity. The family size was generally small with between four and eight members. Twelve of the children had their own bedrooms, the others shared with one other person, usually a sister or brother. Based on this, one can conclude that the respondents were likely to have a quiet place where they could read which is important in reading motivation (Krashen 1993:193).

Only five of the homes did not have radio and the children listened mainly to music and occasionally to the station broadcasting in their home language. Radio can play an important role in preliteracy experience for children whose parents do not read to them. Stories are broadcast which can familiarize children with story structure. It can also increase vocabulary and knowledge of the outside world.

Only two of the homes did not have television. The children admitted to watching two to five hours of television a day, but judging from the programmes watched it may have been even higher especially during weekends. One child when asked how much television he watched, replied, 'lots'. Little of their television watching was mediated by parents. The parents predominantly watched soap operas and/or the news. The children did not join their parents in watching television or discuss programmes they had watched with their parents. Television was the main media form available in all the homes and children spent a great deal of their free time watching television. Research indicates that although television watching may be beneficial for young children from deprived homes, excessive watching of television may have a negative effect on reading, especially on older children, as it displaces this important activity (Neumann 1988:422).

Home literacy experience appears to be limited. The number of books in the homes of the children interviewed varies from none to 50 . Only one child had 50 books in the home - a white Afrikaans-speaking child who had been interviewed because he was one of the best readers in the control school. The other homes averaged a maximum of one book 
per occupant. Some of the children could not differentiate between a book, comic and magazine so in some homes there may have been even fewer books. This also indicates a lack of emergent literacy skills.

When asked to name some of the book titles at home the only titles identified were the Bible, Nelson Mandela's biography A long walk to freedom, and Snow White. The one child stated that 'they are not the type that I want to read'.

All the parents worked in white collar jobs (e.g. doctor, salesman, teacher, policeman). Studies by Heath (1982, 1983, 1986) indicate that the type of work done by parents (or the person with whom the child lives) can play an important role in the child's attitude towards literacy and text. Although the parents were in jobs where text and reading was likely to play an important role this was not reflected in their homelife where there was a limited amount of reading matter in the respondents' homes and reading appears to be minimal.

Most children were not members of a public library. Some did not even know what a public library was. One reason for this may be the relatively few public libraries in black townships (Nassimbeni 1990).

The children do not observe their parents reading books in their leisure time. Most of the fathers read a newspaper - the Sowetan, the City press or the Citizen. Magazines are also present in some of the homes. The magazines are of the sensational or romance genre. The parents were positive role models as the children did see them reading magazines and newspapers. However, they did not observe parents reading books nor did parents appear to endorse reading as an activity for the children either through spending time reading books with the child, purchasing books for the children or encouraging them to join a public library. As Wells (1986:193) has indicated parents are important role models for children in literacy experiences.

The home literacy environment appears very similar to that of the Roadville community as described by Heath (1982:5764). These children do well in literacy events in the first few years at school but in later years they have problems with decontextualized language and comparisons because of limited preliteracy experience. This was demonstrated in the children's inability to deal with inferential questions in the comprehension tests.

The children seem to have had little preliteracy experience. Although the children claim that they were read to as young children only one child could name a favourite book which was read to her. The child who named Snow White as her favourite book stated that this book was bought for her by her mother when she was three and read to her so often that she learnt it off by heart. When asked if younger siblings are read to the majority said 'no' which supports this conclusion. Both parents work and the children appear to have little supervision in the afternoons. Parents are busy with chores when they get home and have little free time to spend with the children. However, some children did mention that grandparents had told them stories which is also an important preliteracy experience.

\section{Reading motivation}

The children claim that they enjoy reading. The one child stated that: 'books make you educated'. However this positive attitude does not appear to motivate them to read in their free time which is largely spent watching television. When asked to name a favourite book only four children were able to do this. The books named were Sleeping Beauty, Snow White, Robinson Crusoe and Klaskat. Only Robinson Crusoe was from the classroom collection.

All the children spoke English as a second language, five spcke an additional language, and one child spoke four languages. However, the medium of instruction at both schools was English. The majority of the children stated that they preferred to read in English rather than in their home language. Studying and reading in a second language may be one of the reasons for lack of reading motivation.

\section{Likes and dislikes}

When asked to indicate what type of books they were interested in reading the majority of the children stated that they preferred books about sport, particularly soccer, animal stories and fairy stories. The only book titles they could name were those of fairy stories such as Sleeping Beauty and Aladdin. Their inability to choose a favourite title may indicate a lack of literacy skills rather than a lack of motivation to read especially if books are attractive and suitable.

The children are very aware of the cultural content of books. The one child stated that he would not read a book titled Xhosa fireside tales because it was about Xhosas and he was Zulu. The school principal informed the researchers that there was conflict on the playground between the Zulu and Xhosa children.

\section{School library}

For many of the respondents the only access they had to books was through the school library. Although both schools had school libraries, the books in the library at the control school were selected for white children who were firstlanguage English speakers. In the experimental school the books were predominantly in Afrikaans. The experimental school had a classroom collection of books specially selected for ESL readers and taking cultural background into account. Although the children were unable to name favourite books from this collection they were obviously enthusiastic about the books when the researchers delivered them or supplemented the collection. Many of the children flipped through the books and expressed an interest in reading them.

\section{Conclusion}

The children all appeared to come from homes which did not actively support important literacy activities. There was a limited number of books and other reading material available at home indicating a lack of a reading culture. There were no marked differences in the literacy environment between 
pupils who had scored well and those who had done badly in the reading tests or those who had read the most and least.

There were strong indications of a lack of preliteracy experience which would mean that children were ill-prepared for the literacy experience at school. Very few of the respondents would have started school with any concept of how a story worked or have internalized a formal story schema or have emergent literacy skills. This would be a demotivating factor as preliteracy skills are a prerequisite to understanding how books work.

Although the children claimed that they spend free time reading and enjoy reading there was little evidence to support this. Many of them understand that education is their passport to a better life, but they do not really understand what education entails (Macdonald 1990). It is therefore probable that reading as an important component of education is regarded as positive, but few of them are likely to engage in this activity out of school hours.

These factors all have a negative effect on literacy as children are not exposed to books at home, there are few shops selling books in African areas (Kantey 1991), and very few libraries. It is difficult to imagine how a child could possibly develop a positive attitude to books or develop a reading habit with such limited access to books. Therefore the school library and classroom collections are essential for encouraging reading.

\section{Recommendations to improve the literacy environ- ment}

With reference to the findings of the literature survey regarding the importance of preliteracy skills and the research projects carried out by both Elley $(1989,1991)$ and Wells (1986), and also taking into account the findings of the indepth interviews, it is important to introduce children to reading activities as early in their schooling as possible. This is of particular importance in communities where children are not exposed to books and book-related activities such as storytelling and reading aloud before they enter primary school. Research (Olën, Machet \& Kloppers 1996) indicates that the younger school children are when introduced to books and reading, the more likely they are to make progress. These children may be more easily motivated to develop the reading habit.

Teachers and librarians also need to talk to parents about literacy occurring as part of everyday family activities at home and the parent's role in providing opportunities and resources, acting as a model for literacy and interacting with the child in reading activities - parents are important role models in literacy activities.

Teachers and librarians could ask parents about the child's favourite book. For those without favourites, teachers and librarians could suggest the family borrow books, show parents the range of books available for young children and explain the importance of children having the opportunity and encouragement to choose a favourite book.
Parents and grandparents can be invited to visit the school and tell stories to children or read to small groups of children. It is important if possible to replicate the intimacy of the parent reading a story to a child because this enables the child who has been deprived of this experience at home to fully participate and share in the book which may not be possible in larger groups.

It is important that the books made available to children are not only comprehensible, but also interesting and relevant if we wish to motivate them to read for pleasure. Although there is some debate about what books African children enjoy reading (Machet 1994, Radebe 1995) according to the teachers, the pupils preferred to use the classroom collection than to borrow books from the school library. The materials in the classroom collection fulfilled the requirements of ESL pupils in terms of language, and cultural accessibility.

However, there were only 2.4 books per pupil. Ideally there need to be at least 12 books per pupil at high-school level and even more books per child at primary-school level (Information power, 1988:117-118; Vermeulen, 1992:115). This also could have been a demotivating factor especially for those children who read a large number of books.

Even where a central school library exists block loans to classrooms can help to promote reading especially in deprived areas for the following reasons:

- They are easily accessible;

- They have been preselected and books have been evaluated from the point of view of vocabulary and level of difficulty;

- Children tend to enjoy books recommended by their peer group. In a limited selection with a number of children selecting books at the same time peer recommendations are likely to take place;

- Children can select a new book as soon as they have finished the one they are reading and do not have to wait for an opportunity to visit the library;

- Children with limited literacy éxperience may be overwhelmed by the size of a centralized school library collection;

- The teacher who has knowledge of the child's ESL ability will be able to guide the child as to the most suitable books; and

- No child will have an excuse not to read during free voluntary reading time as there will always be a supply of books and other material from which the child can select something to read.

It is important to ensure that the books selected for the classroom collection are as accessible and appealing as possible because the children who are not from a reading culture need every possible motivation to read. Research indicates that children have a more positive attitude towards reading if characters in a book reflect the ethnicity, lifestyle and values of the readers (Saracho \& Dayton 1991:43, Shelley-Robinson 1996:16). However, this does not mean they should not be exposed to other cultures and experiences outside their immediate environment. Radebe's research 
(1995) has indicated that children also enjoy books reflecting other cultures and events outside their immediate experience. This type of book expands a child's framework and knowledge of the outside world.

Another important factor in motivating ESL children with limited preliteracy experience to read is accessibility of text and illustrations. The text has to be simple taking into account that it is intended for second-language readers. Some texts are deceptively simple in that sentences are simplified by leaving out causal connections such as 'because'. However, these texts are often more difficult for the child to understand because of implicit assumptions that the child may be unable to follow. The text should be carefully examined not only for vocabulary but also for hidden assumptions that the child may not be in a position to understand. Books that reflect situations and characters that the children are able to identify with and give the children positive role models should be included (Machet 1994, 1995). There should be books to cater for children of all abilities. Even the weakest reader should be able to find a suitable book but the more competent readers in the class should be stretched.

Since access to books is a critical factor in early literacy development it is a good idea to send books home regularly with children.

In areas where there is a high rate of illiteracy books should be issued together with a cassette tape of someone reading the story. The cassette must be issued automatically with the book so that a child who comes from an illiterate home does not have to admit this. Most homes in South Africa have tape recorders on which these cassettes can be played back. The parent then does not have to feel inadequate if they cannot read. This experiment was carried out in England with a small group of children and according to anecdotal evidence was very successful (Gaines 1995). Not only did the children perform better once they got to school in terms of learning to read but it had an additional effect of improving older siblings' literacy as they would listen to the tape together with the child and follow the story in the book. Younger siblings are also exposed to stories and books at an earlier age.

Issuing a cassette tape together with a book is important even for children who do not come from illiterate homes as many parents work and still have household chores when they get back home so they often do not have the time or energy to read to the child.

As public libraries are often inaccessible to Africans, the importance of the school library in the promotion of reading cannot be sufficiently emphasized. Unfortunately in cashstrapped countries where many demands are made for the provision of basic facilities, a school library and a teacherlibrarian are perceived as luxuries that cannot be afforded. Nevertheless, the teacher-librarian has a crucial role to play in the promotion of a culture of reading and learning. S/he has the expertise to select appropriate books, for both block loans to classrooms and for individual pupils. The teacher-librarian can keep a proper record of each pupil's reading, motivate good readers to read more challenging books and help the language teachers to motivate pupils to read by using a range of reading promotion activities.

Although the sample is too small to enable one to generalize, looking at the high rates of illiteracy and lack of a reading culture in many areas in South Africa it can be assumed that very few children will come to school with the necessary preliteracy skills to be good readers. It is therefore essential that schools have school libraries and librarians to help motivate children to read and encourage the development of a reading culture which is essential for school success. It will be false economy to do away with such a basic and essential resource.

\section{Acknowledgement}

The authors wish to acknowledge the assistance they received from Marie Kloppers in carrying out the research project.

\section{References}

Alspaugh, J. 1991. Out-of-school environmental factors and elementary-school achievement in mathematics and reading. Journal of research and development in education, 24(3):53-56.

Anderson, R.C., Wilson, P.T. \& Fielding, L.G. 1985. Becoming $a$ nation of readers: the report of the Commission on Reading. Washington, DC: National Institute of Education.

Come, B. \& Fredericks, A.D. 1995. Family literacy in urban schools: meeting the needs of at-risk children. Reading teacher, 48(7): 566-570.

Dickenson, D.K., De Temple, J.M., Hirschler, J.A. \& Smith, M.W. 1992. Book reading with preschoolers: coconstruction of text at home and at school. Early childhood research quarterly, 7:323346.

Edwards, P.A. 1995. Empowering low-income mothers and fathers to share books with young children. Reading teacher, 48(7):558564.

Elley, W.B. 1989. Vocabulary acquisition from listening to stories. Reading research quarterly, 24(2):174-187.

Elley, W.B. 1991. Acquiring literacy in a second language: the effect of book-based programs. Language learning, 41(3):375-411.

Elley, W.B. \& Mangubhai, F. 1983. The impact of reading on second-language learning. Reading research quarterly, 19(1):5367.

Filson, A.H. 1992. Librarian-teacher partnerships: serving the English-as-a-second language students. Journal of youth services in libraries, 5(4):399-406.

French, E. 1988. The reading world of black workers. M Ed dissertation. University of the Witwatersrand, Johannesburg.

Gaines, K. 1995. Personal interview, Pretoria, 11 September.

Harris, K. \& Baskin, B. 1989. Toward a culturally literate society. School library journal, 35(12):29-32.

Heath, S.B. 1982. What no bedtime story means: narrative skills at home and at school. Language in society, 11:49-76.

Heath, S.B. 1983. Ways with words: language, life and work in communities and classrooms. Cambridge: Cambridge University Press.

Heath, S.B. 1986. The functions and uses of literacy, in Literacy, society and schooling: a reader. ed. S. de Castell, A. Luke, K. Egan. Cambridge: Cambridge University Press:1526.

Information power: guidelines for school library media programs. 1988. Chicago: American Association of School Librarians and Association for Educational Communications and Technology. 
Kantey, M. 1990. Forward: publishing in South Africa, in Africa bibliography, 1989. Manchester: Manchester University Press:vixx.

Kantey, M. 1991. New approaches to marketing and distribution, in Book publishing in South Africa for the 1990s. Proceedings of a symposium held at the South African Library, Cape Town 22-25 November 1989. Cape Town: South African Library:100-117.

Kinnell, M. 1995. Policy for secondary school library provision in England and Wales: an historical perspective. Journal of librarianship and information science, 27(1):17-26.

Krashen, S.D. 1989. We acquire vocabulary and spelling by reading: additional evidence for the input hypothesis. Modern language journal, 73(4):440-464.

Krashen, S.D. 1993. The power of reading: insights from the research. Englewood: Libraries Unlimited.

Lance, K.C., Welborn, L. \& Hamilton-Pennell, C. 1993. The impact of school library media centres on academic achievement. Castle Rock, Colo.: Hi Willow Research and Publishing.

Liddell, C. 1987. Some issues regarding the introduction of preschool enrichment programmes for black South African children. International journal of educational development, 7(2):127-131.

Macdonald, C.A. 1990. Crossing the threshold into standard three in black education. The consolidated main report of the Threshold project. Pretoria: Human Sciences Research Council.

Machet, M.P. 1994. Black children's ability to access western literate stories. South African journal of library and information science, 62(2):65-74.

Machet, M.P. 1995. Socio-cultural background as a factor in acquisition of narrative discourse skills. Australian journal of language and literacy, 18(4):281-292.

Miles, B. 1995. Helping children learn to love reading as much as we do. Youth services in libraries, 9(1):33-43.

Morrow, L.M. \& Weinstein, Carol S. 1986. Encouraging voluntary reading: the impact of a literature program on children's use of library centers. Reading research quarterly, 21(3):330-346.

Nassimbeni, M. 1990. Professional education for library acquisitions in South African library schools. Library acquisitions: practice and theory, 14(1):73-79.

Neumann, 1988. The displacement effect: assessing the relation between television viewing and reading performance. Reading research quarterly, 23(4):414-440.

Olën, S.I.I. 1990. Promoting reading aloud to the parents and other childminders of preschool children. South African journal of library and information science, 58(4):382-387.

Olën, S.I.I. \& Machet, M.P. 1997. Research project to determine the effect of free voluntary reading on comprehension. South African Journal of library and information science, 65(2):85-92
Olën, S.I.I., Machet, M.P. \& Kloppers, M. 1996. The efffect of free voluntary reading by primary school pupils on their English second language. Pretoria: Centre for Library and Information Science, University of South Africa. (Unpublished report).

Olson, D.R. \& Astington, J.W. 1990. Talking about text: how literacy contributes to thought. Journal of pragmatics, 14:705721.

Radebe, T. 1995. Reading interests of Zulu-speaking Standard Two children in Pietermaritzburg. South African journal of library and information science, 63(4): 161-172.

Ross, K.N. \& Postlethwaite, T.N. 1994. Differences among countries in school resources and achievment, in The IEAstudy of reading literacy: achievement and instruction in thirty-two school systems. ed. Warwick B. Elley. Oxford: Pergamon:123-148.

Saracho, O.N. \& Dayton, C.M. 1991. Age-related changes in reading attitudes of young children: a cross-cultural study. Journal of research in reading, 14(1):33-45.

Shelley-Robinson, C. 1996. The voluntary reading interests and habits of Jamaican sixth graders. Paper presented at Conference: International Association of School Librarianship, 25th Annual Conference, Jamaica, 30 July1996. (Unpublished paper).

Simmons, D. 1994. It takes more than a book talk: prereading strategies. Emergency librarian, 21(5): 18-29.

Snow, C.E. \& Ninio, A. 1986. The contracts of literacy: what children learn from learning to read books, in Emergent literacy: writing and reading, ed. W.H. Teale, E. Sulzby. Norwood, N.J.: Ablex:116-138.

Thembela, A.J. 1982. Equality in education - an idle dream?, in Proceedings of the National Education Conference: The De Lange Report: assessment and implementation, the future of education in South Africa, 4-6 Feb. ed. R. Tunmer. Grahamstown: The 1820 Foundation:13-16.

Tötemeyer, A.J. 1994. Speaking from a book: the transfer of derecorded information to the information starved. IFLA journal, 20(4):410-418.

Trelease, J. 1995. Reading aloud for reading readiness. Youth services in libraries, 9(1):43-53.

Vermeulen, W.M. 1992. Quantitative standards for school libraries in South African secondary schools. South African journal of library and information science, 60(2):114-120.

Weinberger, J. 1996. A longitudinal study of children's early literacy experiences at home and later literacy development at home and school. Journal of research in reading, 19(1):14-24.

Wells, G. 1986. The meaning makers: children learning language and using language to learn. London: Hodder \& Stoughton.

White, B.L. 1985. The first three years of life. Rev ed. New York: Prentice-Hall. 